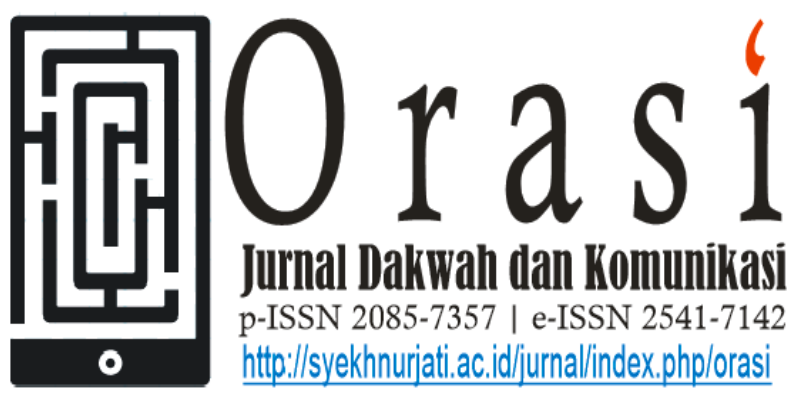

Volume 12 No. 2 Desember 2021

\title{
PEMBENTUKAN KATA BARU MELALUI PROSES BLENDING SEBAGAI IDENTITAS PERUSAHAAN DALAM KOMUNIKASI PEMASARAN
}

\section{NEW WORD FORMATION THROUGH BLENDING PROCESS FOR A COMPANY IDENTITY IN MARKETING COMMUNICATION}

\author{
Arif Budiwinarto',a), Mursyid Kasmir Naserly² \\ ${ }^{1}$ Prodi Ilmu Komunikasi Buddha, STABN Sriwijaya Tangerang \\ ${ }^{2}$ Prodi Bahasa Inggris, Universitas Bina Sarana Informatika Cengkareng \\ a)e-mail: arifbudiwinarto@stabn-sriwijaya.ac.id
}

\begin{abstract}
ABSTRAK
Manusia melakukan komunikasi dalam upaya mencapai tujuannya. Dalam proses komunikasi terdapat interaksi antara komunikator dan komunikan menggunakan bahasa sebagai saluran (media) penyampai pesan. Memiliki sifat unik, bahasa dapat dimanfaatkan untuk berbagai kepentingan, termasuk sebagai identitas perusahaan dalam komunikasi pemasaran. Bahasa dapat dimodifikasi serta menghasilkan kata baru melalui proses morfologi, khususnya blending. Pembentukan kata baru melalui proses blending merupakan proses kreatif yang menarik dalam berbagai bidang mencakup juga komunikasi pemasaran. Penelitian ini menganalisa proses morfologis pembentukan kata baru sebagai tagline produk jasa yang diliuncurkan oleh perusahaan retail Ace Hardware serta implementasinya sebagai identitas perusahaan dalam perangkat promosi (promotion tools). Penulis meneliti penciptaan kata baru dalam tagline Acesistant melalui proses morfologis blending menurut Adriene Lehrer dan John Algeo, serta analisis penggunaan tagline sebagai identitas perusahaan dalam perangkat promosi. Hasil penelitian menunjukkan pembentukan kata baru melalui proses morfologis blending mampu menghasilkan sebuah tagline produk jasa yang merepresentasikan identitas sebuah institusi bisnis. Lebih jauhnya, tagline juga berfungsi sebagai komponen promosi dalam komunikasi pemasaran yang menonjolkan ciri khas.
\end{abstract}

Kata Kunci: Blending, Identitas Perusahaan, Komunikasi Pemasaran 


\begin{abstract}
Human beings communicate significantly to find their goals. In the communication process, there is an interaction between the communicator and the communicant involving language, which has a role as a channel (a medium) to deliver messages. Having unique characters, language can be implemented for various purposes, including marketing communication. Language can also be modified to ptoduce new words through morphological processes, specifically blending process. A new word formation through a blending process is considered an interesting creative process in various fields, especially marketing communication field. Ace Hardware implemented this process by introducing their new customer service tagline to the public. This study analyzes the morphological process in forming a new word as a tagline for customer service, which had been announced by the retail company, Ace Hardware. Moreover, this study also explores the tagline implementation as a promotional tool in marketing communication. The writers discovered a new word formation of Acesistant tagline through a morphological blending process as stated by Adriene Lehrer and John Algeo, as well as analyzed the tagline usage as a company identity. The writers concluded that the Acesistant tagline derived from a morphological blending process could represent the company's identity, as well as function as a promotional tool which highlighted the specialty in marketing communication.
\end{abstract}

Keywords: Blending, Company Identity, Marketing Communication

\section{Pendahuluan}

Sebagai makhluk sosial, yang membutuhkan orang lain untuk memenuhi kebutuhannya, manusia melakukan proses komunikasi. Di dalamnya terdapat interaksi antara pembicara (komunikator) dan pendengar (komunikan) guna memperoleh apa yang diharapkan. Proses komunikasi tidak dapat dipisahkan dari peran bahasa. Bahasa merupakan perangkat (tool) yang digunakan oleh manusia untuk bertukar ide, gagasan, perintah serta mempengaruhi perilaku dan sikap.

Harimurti Kridalaksana (Kushartanti 2005) menyebut bahasa sebagai sebuah sistem dan suara yang disepakati untuk dipakai oleh sebagian kelompok dalam masyarakat untuk bekerjasama, berkomunikasi, dan mengindentifikasi diri mereka (1). Thomas Stewart (Stewart 2001) mengungkapkan bahwa sebuah bahasa menyentuh setiap bagian dari hidup manusia, bahasa memberikan katakata bagi pikiran kita, suara untuk ide-ide kita serta ekspresi untuk menunjukkan perasaan.

Bersifat arbiter membuat bahasa semakin dinamis dari waktu ke waktu. Artinya, bahasa bisa dipengaruhi fenomena sosial serta kepentingan penggunaan. Bahasa juga memiliki sifat unik, yang menelurkan kosakata baru dari setiap penuturnya. Sifat ini memungkinkan bahasa mengalami modifikasi baik secara leksikal maupun gramatikal. Proses modifikasi bahasa tak terlepas dari buah kreatifitas penggunanya yang disesuaikan dengan tren pemanfaatannya.

Lahirnya sebuah bahasa atau kata baru dapat dikaji dalam Morfologi. Menurut Booij (Anita; Ramadhiyanti; Kurniawati 2014) morfologi dapat dikategorikan sebagai subdisiplin linguistik yang terkait dengan 
hubungan bentuk dan makna dari sifat dasar yang sistematik. "Morphology is the sub discipline of linguistics that deals with a relation in form and meaning of a systematic nature."

Dalam kajian morfologi terdapat akronim, blending dan clipping yang merupakan aspek-aspek dari pembentukan kata baru yang kerap hadir dengan proses pembentukan kata baru yang umumnya mengutamakan bunyi yang bagus atau enak didengar (Zaim 2015). Dari tiga aspek pembentukan kata tersebut, blending merupakan pola pembentukan kata yang sudah sangat umum terjadi di masyarakat. Menurut Yule (Giyatmi; Wijayava; Arumi 2018)Blending merupakan peleburan dua kata atau lebih yang ditujukan untuk menghasilkan satu kata dengan wujud yang benar-benar baru.

Blending memiliki karakter kata yang sulit dikenali bentuk asli atau kata dasarnya. Hal ini disebabkan oleh terdapatnya metode shortened (pemendekan) kata pada salah satu kata yang melebur didalam proses blending. Pendapat yang dipaparkan oleh Algeo dalam Hosseinzadeh tersebut kemudian diperdalam lagi oleh Delahunty dan Garvey. Dalam pernyataannya, Delahunty dan Garvey menggunakan istilah removing (penghilangan) bagian kata untuk mengganti istilah pemendekan (shortening) maupun pemotongan (clipping). Setelah sebagian kata dihilangkan kemudian sisa kata yang tidak dihilangkan digabung untuk membentuk kata yang baru yang disebut blends. Beberapa contoh umum blending antara lain
Motor + Hotel $=$ Motel dan Spanish + English $=$ Spanglish.

Hadirnya blending dalam pembentukan kata baru tentu dianggap sebagai suatu proses kreatif yang menarik dalam berbagai bidang, khususnya komunikasi pemasaran.

Selain menghadirkan keefisienan berbahasa, blending dapat dipakai sebagai alat promosi dalam mendukung pemasaran sebuah merek. Dalam komunikasi pemasaran, kekuatan kata-kata sebagai tagline sebuah merek dagang merupakan bagian dari strategi periklanan. Dalam bukunya, Shimp (Shimp. Terence 2014) menyebut strategi ini memberikan copywriter pemahaman tentang bagaimana kerja kreatif mereka harus sesuai dengan komunikasi pemasaran secara keseluruhan yang meliputi beberapa elemen selain iklan.

Sedangkan pesan yang dapat disampaikan kepada target audiens fokusnya adalah terhadap manfaat dari merek tersebut, bukan atribut produk. Sebab, kredibilitas dan kepercayaan adalah kunci untuk audiens supaya menerima proposisi pesan tersebut, elemen dari laporan kreatif ini mendukung proposisi dengan bukti adanya atribut produk yang menyokong manfaat yang diklaimnya.

Di era internet of things (Iot) semakin banyak perusahaan memanfaatkan media digital sebagai saluran promosi dengan menyertakan tagline. Merujuk pada kamus Bahasa Inggris, pengertian tagline identik dengan slogan yang juga sejalan dengan konteksnya dalam dunia marketing dan promosi. Tagline bukan hanya sebatas slogan 
namun juga identitas produk dan menjadi ciri khas pembedanya.

Langkah tersebut diimplementasikan oleh Ace Hardware dengan memperkenalkan ke publik tagline Acesistant dalam layanan konsumen melalui platform digital. Acesistant merupakan bentuk pembaruan aplikasi untuk layanan konsumen eksklusif yang sebelumnya tidak ditemukan pada versi lawas aplikasi konsumen Ace Hardware. Acesistant merupakan kata baru yang lahir dari proses morfologis buah kreatifitas copywriter, sehingga menghasilkan sebuah tagline yang unik dan menunjukkan identitas produk layanan konsumen yang khas.

Dari pemaparan di atas maka rumusan masalah dalam penelitian ini adalah bagaimana proses morfologis pembentukan tagline Acesistant yang diluncurkan oleh Ace Hardware serta implementasinya sebagai identitas perusahaan dalam perangkat promosi (promotion tool).

Berdasarkan pemaparan di atas, rumusan masalah dalam penelitian ini adalah bagaimana proses lahirnya sebuah kata baru yang digunakan sebagai promotion tools sebagai representasi identitas perusahaan. Peneliti melakukan riset guna memahami proses pembentukan kata/istilah baru dalam kajian Linguistik yang disebut blending, kemudian menganalisa pemanfaatannya sebagai penguatan ciri khas perusahaan.

Blending merupakan suatu metode pembentukan kata yang memadukan dua komponen kata atau lebih dengan tujuan untuk menghasilkan satu bentuk kata baru. Metode peleburan kata ini serupa dengan istilah compounding. Hanya saja hasil kata dari compounding masih dapat dikenali bentuk aslinya, contoh toothpaste, bedroom, software, break dance dan public speaking. Istilahistilah tersebut merupakan hasil dari perpaduan kata melalui proses compounding. Sebaliknya, blending menghasilkan kata yang belum pernah ada sebelumnya. Kata yang dibentuk dari proses blending menimbulkan konsekuensi penutur perlu beradaptasi dan mempelajari cara pengucapannya terlebih dahulu, sebelum benar-benar lugas dalam menyebutkan kata baru tersebut.

Identitas perusahaan (corporate identity) salah satu fungsinya adalah sebagai perangkat pemasaran (tools of promotion). Menurut PR Smith (Smith 1998) identitas perusahaan adalah makna visualisasi dari apa yang menjadi ciri-ciri perusahaan dan/atau organisasi. Sedangkan William F. Arens (Arens 1996) menjelaskan identitas perusahaan sebagai "upaya memperkenalkan perusahaan kepada publik dengan membuat nama, logo, paten, ciri khas, khususnya setelah banyak hal yang berubah". Sementara Rossiter dan Percy (Rossiter, J.R., dan Larry 1997) mendefinisikan identitas perusahaan sebagai "cara bagaimana sebuah perusahaan mengenalkan dirinya secara visual menggunakan nama, logo, penanda, laporan tahunan, alat tulis, seragam, kendaraan, kemasan, dan simbol-simbol terlihat lainnya".

Identitas perusahaan sebagai perangkat promosi berbeda dengan periklanan dan public relations. Identitas perusahaan merupakan sebuah aset strategis yang membantu untuk mencapai tujuan komunikasi pemasaran 
jangka panjang. Sebagai aset, identitas perusahaan perlu dipelihara serta dijaga, jika terjadi kekacauan maka stakeholders' harus segera melakukan mitigasi isu/ancaman serta memproyeksikan pemulihan citra.

Dari pemaparan di atas, identitas perusahaan merupakan sebuah sistem yang menggunakan semua poin yang memiliki kontak dengan publik. Identitas perusahaan menjadikan strategi perusahaan dapat dilihat melalui desain dan hal itu dapat menjawab tiga hal berikut: (1) siapa Anda (perusahaan), (2) Apa yang dikerjakan, dan (3) bagaimana mengerjakannya. Identitas perusahaan yang paling banyak bersentuhan dengan kehidupan masyarakat sehari-hari adalah merek (brand) dan logo.

Merek merupakan rancangan unik suatu perusahaan. Ketika perusahaan dapat memberikan pembeda pada penawarannya dari kategori produk perusahaan lain, maka konsumen seringkali mengingat merek dagang (trademark) tersebut. Artinya, merek merupakan salah satu aspek komunikasi pemasaran yang paling penting (Thomas, $\mathrm{S}$. Robertson dan Harold, Kassarjian (ed). Englewood 1991). Joseph W. Alba, J. Wesley Hutchinson dan John G. Lynch (Thomas, S. Robertson dan Harold, Kassarjian (ed). Englewood 1991) menyatakan mereka yang baik dapat membangkitkan perasaan berupa kepercayaan, keyakinan, keamanan, kekuatan, keawetan, kecepatan, status, dan asosiasi lain yang diinginkan.

Ada tiga efek merek yang diharapkan muncul, yakni (1) memengaruhi kecepatan konsumen menyadari suatu merek, (2) memengaruhi citra merek, (3) memainkan peran penting dalam pembentukan ekuitas merek.

Dalam penelitian ini, merek direpresentasikan dalam bentuk tagline produk/jas. Seringkali tagline dikreasi dengan memasukkan unsur penamaan merek dagang atau identitas simbolik lainnya seperti font dan warna.

\section{Metodologi Penelitian}

Dalam penelitian ini, peneliti menggunakan pendekatan kualitatif dengan analisis morfologis pembentukan kata menurut Adriene Lehrer dan John Algeo, serta penggunaan tagline sebagai corporate identity dalam komunikasi pemasaran. Objek penelitian ini adalah tagline Acesistant dalam aplikasi digital terbaru yang diluncurkan Ace Hardware.

Teknik pengumpulan data dalam penelitian ini menggunakan kepustakaan dan dokumentasi. Dalam menganalisis data, peneliti menggunakan analisis blending Lehrer dan Algeo serta analisis bahasa sebagai identitas perusahaan dalam perangkat promosi (promotional tools). Lehrer dan Algeo merupakan dua tokoh linguistik yang mengemukakan ketegori-kategori pembentukan kata/terminologi baru melalui proses blending sebagai bagian dari dari morfologi. Menurut Lehrer, blending terbagi dalam empat kategori, sementara Algeo mengembangkan konsep blending yang dikemukan oleh Lehrer menjadi enam kategori. 
Sebagai perangkat promosi, bahasa memainkan peran penting baik dalam tuturan langsung maupun dalam bahasa tulis. Bahasa yang dipakai untuk promosi bukan hanya berupaya mempersuasi khalayak mengenai merek tetapi juga berfungsi sebagai identitas perusahaan. Identitas perusahaan merupakan aset penting yang membantu untuk mencapai tujuan komunikasi pemasaran dalam jangka panjang. Secara umum, identitas perusahaan kerap direpresentasikan secara visual dengan logo, warna, atau seragam (Rossiter, J.R., dan Larry 1997).

\section{Hasil dan Pembahasan}

\subsection{Analisa Blending Menurut Lehrer}

Menurut Lehrer (Lehrer

2007)blending diklasifikasikan menjadi empat kelompok.Blending kelompok pertama terbentuk dengan menggabungkan seluruh kata asal (source word) pertama dan kemudian diikuti dengan bagian potongan kata asal (splinter) seperti contoh wintertainment merupakan penggabungan kata winter dan entertainment. Kelompok kedua adalah blending yang terjadi melalui penggabungan splinter kata pertama kemudian diikuti oleh kata asal kedua secara utuh, seperti contoh Amerindian berasal dari kata America dan Indian. Selanjutnya di kelompok ketiga, blending terbentuk dari dua splinter, baik dari bagian awal kata pertama diikuti oleh bagian akhir kata asal kedua. Contoh blending kelompok ketiga terdapat pada kata hurricoon, yang merupakan penggabungan dua kata hurricane dan typhoon, contoh lainnya sitcom hasil penggabungan kata situational dan comedy. Kelompok keempat, Lehrer menyimpulkan bahwa blending dapat pula terjadi dengan cara overlap (tumpang tindih) dari satu atau lebih suara. Hal ini tentu akan membuat kata blending di kelompok empat ini memiliki bunyi yang mirip pada dua kata asal seperti sexploitation, penggabungan kata sex dan exploitation yang memiliki kesamaan bunyi di suku kata awal serta sexpert yang terbentuk dari dua kata, sex dan expert.

Mengacu pada empat bentuk blending menurut Lehrer, kata Acesistant masuk kedalam kategori pertama. Kata Ace, yang merupakan kata pertama mewakili merek dagang Ace Hardware, digunakan secara utuh kemudian digabung dengan kata dasar Assistant yang digunakan sebagian untuk membentuk kata baru dengan pola pembentukan Ace + (As)-sistant .

\subsection{Analisa Blending Menurut Algeo}

Selain Lehrer, Algeo dalam Hosseinzadeh (Hosseinzadeh 2014) juga memaparkan pandangannya mengenai produksi kata baru melalui proses blending. Algeo mendalami apa yang sudah ditemukan oleh Lehrer menjadi lebih fokus dalam formula blending berjenis pemotongan (clipping). Kemudian temuan tersebut diklasifikasikan lagi lebih lanjut menjadi enam jenis yaitu; (1) blending yang terbentuk dengan cara bagian awal kata pertama dan bagian akhir kata kedua, seperti chexting hasil penggabungan kata cheating dan texting, cosmeceutical dari kata cosmetic dan pharmaceutical, dan globish hasil dari 
perpaduan kata global dan English, (2) blending yang tetap mempertahankan keseluruhan bagian kata pertama dan bagian terakhir kata kedua, seperti babelicious berasal dari kata babe dan delicious, foodoholic penggabungan dari kata food dan alcoholic, dan blacktress dari kata black dan actress, (3) blending yang mempertahankan bagian kata pertama dan keseluruhan kata kedua, seperti Eurasia menggabungkan kata Europe dan Asia, Cheaster dari kata Christmas dan Easter, dan automagic gabungan kata automatic dan magic, (4) blending yang terbentuk dengan menggunakan bagian pertama dari dua kata asal, seperti pokemon penggabungan kata pocket dan monster, famicom berasal dari kata family dan computer, dan avgas hasil gabungan kata aviation dan gasoline, (5) blending yang terbentuk dengan cara penggabungan suara ganda dari dua kata, seperti slithy dihasilkan dari kata lithe dan slimy, dan daisy penggabungan kata day's dan eye, serta (6) blending yang terbentuk dengan menggunakan bagian akhir dari dua kata asal, seperti ipodcasting gabungan dari ipod dan broadcasting.

Mengacu pada enam kategori blending yang dipaparkan oleh Algeo, kata Acesistant dikategorikan masuk ke dalam proses blending yang tetap mempertahankan keseluruhan bagian kata pertama. Penjelasannya, Ace sebagai kata pertama dari Ace Hardware dipadukan dengan bagian terakhir kata kedua ((As)-sistant). Dengan demikian, kata baru Acesistant lahir dari proses pemotongan (clipping) pada kata asal kedua.
Hal unik dari kata Acesistant sebagai hasil dari proses blending dalam penelitian ini adalah kata Ace yang berada pada awal proses bentukan kata tidak memiliki definisi pemaknaan, sebab ia merupakan penggalan dari satu keutuhan merek dagang Ace Hardware, namun demikian tidak serta merta mengeleminasi atau mengaburkan esensi identitas yang diwakilinya. Sehingga khalayak, baik itu pelanggan maupun target potensial, tetap mampu mengidentifikasi Acesistant sebagai tagline yang identik dengan Ace Hardware, bukan dari brand lain.

\subsection{Bahasa Sebagai Identitas Perusahaan Dalam Perangkat Promosi}

Bahasa, dalam penelitian ini berupa tagline, berdasarkan penjelasan Rossiter dan Percy (Rossiter, J.R., dan Larry 1997) merupakan simbol terlihat yang mendefiniskan identitas perusahaan. Termasuk dalam perangkat promosi, identitas perusahaan merupakan proses yang direncanakan. Tagline Acesistant pertama kali diperkenalkan ke publik pada 4 November 2020 bersamaan dengan perayaan HUT ke-25 Ace Hardware.

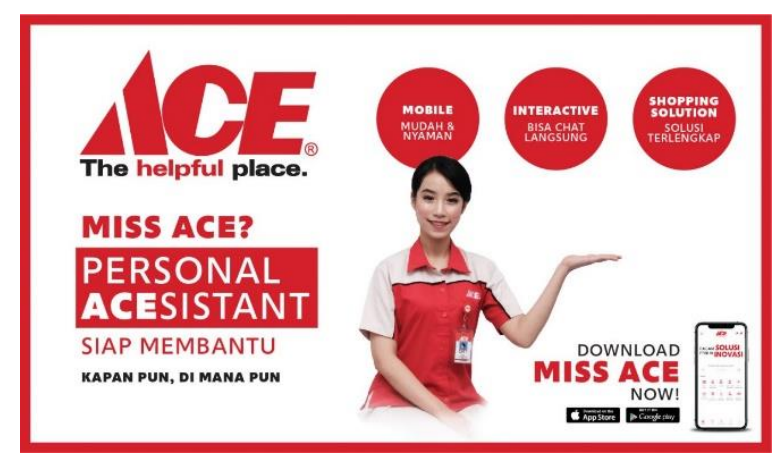

Gambar 1. Banner iklan pelayanan konsumen Acesistant dari Ace Hardware

Acesistant merupakan tagline baru dalam layanan aplikasi Mobile Interactive 
Shopping Solution (MISS ACE) yang merupakan pengembangan layanan pada aplikasi mobile ACE INDONESIA yang diluncurkan tahun 2016. Pada banner di atas, terlihat kata "Acesistant" bersanding dengan kata "Personal" dengan warna font putih serta latar belakang merah. Pemilihan simbolsimbol nonverbal tersebut merupakan proses konsisten stimulus visual terhadap kesadaran terhadap perusahaan, terutama pengenalan perusahaan (recoginition) dan juga meningkatkan kembali kesadaran (awareness) tentang perusahaan.

Dalam taglineAcesistant, Ace Hardware sebagai salah satu perusahaan retail terkemuka di Indonesia berupaya memelihara identitas perusahaan. Bila merujuk pada pernyataan Rossiter dan Percy (Rossiter, J.R., dan Larry 1997)taglineAcesistant merupakan aset strategis yang membantu untuk mencapai tujuan komunikasi pemasaran dalam jangka panjang. Penjelasannya, dalam taglineAcesistant masih tetap mempertahankan simbol nonverbal perusahaan/merek dagang yang diwakili kata Ace merupakan penggalan dari Ace Hardware dalam proses blending.

Sedangkan kata Acesistant dalam tagline Personal Acesistant pada aplikasi MISS ACE berupaya merefleksikan kepribadian, nilai inti dan arahan perusahaan. Hal ini merupakan komunikasi satu arah perusahaan yang berkaitan dengan nilai-nilai yang ingin diekspresikan. Tagline "Personal Acesistant" memiliki kemiripan pengucapan dengan frasa Personal Assistant yang berarti asisten pribadi. Dalam case ini, asisten pribadi yang dimaksud adalah operator dalam aplikasi mobile MISS ACE untuk membantu pelanggan memperoleh informasi mengenai deskripsi produk, penawaran harga spesial, layanan customer service ACE Hardware melalui online chatting, e-mail, telepon dan sms serta Member ACE Rewards.

"Dengan mengunduh atau mengupdate system aplikasi mobile, seluruh pelanggan bisa memanfaatkan layanan MISS ACE untuk merasakan pengalaman berbelanja yang lebih nyaman, seperti memiliki Personal ACEsistant," bunyi pernyataan Malvin Tarigan, Marketing Senior Manager PT. ACE Hardware Indonesia seperti dikutip dari Kompas.com.

\subsection{Mengelola Identitas Perusahaan dengan Tagline}

Smith (Smith 1998) mengemukakan tentang beberapa tahap dalam pengelolaan identitas perusahaan diantarnya; memahami situasi saat ini dan menentukan citra ideal, implementasi peluncuran dan pemeliharaan serta tinjauan ulang dan pembaharuan. Penggunaan taglinePersonal Acesistant dalam aplikasi MISS ACE lebih luas merupakan upaya ACE Hardware memperkuat citra serta nilai pelayanan perusahaan. Hal ini merupakan sistem visual yang menggunakan semua poin yang memiliki kontak dengan publik, dalam hal ini adalah pelanggan atau calon pelanggan. Di dalamnya termasuk infrastruktur permanen atau bangunan, sumber daya manusia, sarana dan format bisnis yang diaplikasikan.

Tagline Personal Acesistant merupakan bentuk adaptasi format bisnis ACE Hardware ke ranah digitalisasi menyesuaikan 
era Internet of Things (IoT) dalam bentuk aplikasi mobile di telepon pintar. Pengembangan aplikasi ini disesuaikan dengan kebutuhan serta perilaku konsumen yang serba praktis dan efisien. Lahirnya taglinePersonal Acesinstant juga secara jelas menunjukkan pergeseran interaksi dan distribusi antara perusahaan dengan konsumen, dari yang awalnya interaksi langsung ditandai dengan kunjungan ke gerai lalu memilih produk dengan melihat fisiknya langsung menjadi transaksi digital. Di masa pandemi Covid-19, inovasi digital menjadi sebuah keniscayaan sebab pemenuhan kebutuhan konsumen harus tetap berjalan tanpa mengabaikan aspek kesehatan dan keselamatan. Pemanfaatan asisten digital seperti yang ditawarkan oleh ACE Hardware melalui "Personal Acesistant" merupakan solusi paling masuk akal. Perubahan ini hadir tidak dalam waktu singkat, akan tetapi melalui perencanaan yang terukur demi keberlangsungan bisnis serta upaya mempertahankan citra perusahaan.

"Dengan penambahan layanan MISS ACE, kini pelanggan dapat berbelanja melalui aplikasi dan memiliki Personal ACEsistant yang akan membantu kapan dan dimanapun," ujar Nana Puspa Dewi selaku Marketing Director Kawan Lama Group, Rabu (4/11/2020), seperti yang dikutip dari Kompas.com.

\subsection{Penggunaan Tagline sebagai Bentuk Penerapan Integrated Marketing Communication (IMC)}

Aktivitas pemasaran tidak bisa lepas dari komunikasi, keduanya menciptakan keterpaduan dalam mencapai tujuan. Komunikasi sebagai sebuah seni menyampaikan pesan serta mempengaruhi khalayak memegang peran krusial dalam pemasaran. Pemasaran membutuhkan komunikasi bukan hanya menciptakan pesan satu arah, akan tetapi mendorong adanya umpan balik kepada perusahaan untuk menentukan bentuk dan metode yang perlu dikembangkan bagi program komunikasi yang dijalankan. Dasar inilah yang mendorong lahirnya Komunikasi Pemasaran Terintegrasi (Integrated Marketing Communication).

Menurut American Association of Advertising Agencies, Komunikasi Pemasaran Terintegrasi (IMC) merupakan upaya kombinasikan pesan-pesan yang terpisah melalui sebuah perencanaan mendalam dengan cara melakukan evaluasi terhadap peran strategis dari ilmu komunikasi (Sulaksana 2003). Sedangkan menurut Philip Kotler dan Gary Amstrong (Kotler, Philip 2001) IMC sebagai konsep di mana suatu perusahaan secara hati-hati mengintegrasikan dan mengkoordinasikan saluran komunikasinya yang banyak untuk menyampaikan pesan yang jelas, konsisten, dan meyakinkan mengenai perusahaan dan produknya. Kegiatan IMC meliputi promosi penjualan, penjualan personal, periklanan dan hubungan masyarakat.

Dari pemaparan di atas, IMC dapat berupa penggunaan seluruh bentuk kontak dalam bentuk komunikasi yang menghubungkan merek sebagai jalur penyampian pesan yang potensial. ACE Hardware menerapkan konsep IMC dengan 
memaksimalkan sumber daya komunikasi yang dimiliki yakni platform digital berupa aplikasi MISS ACE yang telah tersedia di PlayStore (bagi pengguna Android) serta AppStore (bagi pengguna IoS). Aplikasi MISS ACE di telepon genggam pintar bukan sekadar menawarkan kemudahan bagi pelanggan dan calon pelanggan dalam memenuhi kebutuhan mereka, lebih dari itu perusahaan secara jelas ingin menciptakan kedekatan dengan customer melalui interaksi digital yang memungkinkan timbulnya interaksi secara terbuka, efisien, dan efektif.

Melalui taglinePersonal Acesistant dalam aplikasi MISS ACE, ACE Hardware berusaha menunjukkan komitmen mereka memberikan pelayanan prima kepada pelanggan. Kehadiran MISS ACE dengan taglinePersonal Acesistant merupakan bentuk adaptasi pada perkembangan komunikasi digital serta menciptakan sinergi semua elemen komunikasi termasuk iklan, tempat pembelian, promosi pembelian, event, dan lain-lain. Tujuannya menghasilkan citra merek yang kuat dan utuh serta membuat konsumen melakukan aksi pembelian.

Dengan taglinePersonal Acesistant, ACE Hardware menawarkan customer sejumlah kemudahan dalam fitu-fitur seperti Free Delivery untuk layanan pengantaran gratis, fitur Digital Member untuk melacak semua transaksi serta benefit sebagai member, fitur Scan\&Shop untuk mengetahui informasi detail produk serta memasukan produk pilihan ke dalam keranjang. Untuk memudahkan customer memilih tempat pembelian terdekat, tersedia fitur Store Locator, sedangkan fitur
Online Special Offer menawarkan banyak program potongan harga spesial serta penjualan tematik seperti Shopping Day 9.9, 10.10 maupun flash sale sebagai bagian dari promosi.

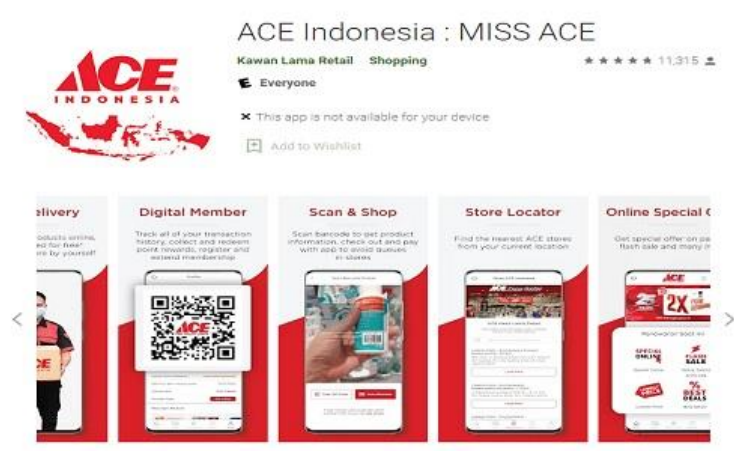

Gambar 2. Tangkapan layar aplikasi ACE Indonesia: MISS ACE dan fitur-fiturnya di PlayStore

\section{Simpulan}

Knapp (Knapp 2001) mengungkapkan bawah tagline merupakan sebuah media komunikasi yang digunakan sebuah brand untuk mengungkapkan berbagai hal yang bersifat dramatis atau emosional sehingga kumpulan kata ekspresif tersebut dapat memengaruhi perasaan setiap pelanggan potensial dari brand tersebut. Penyematan identitas perusahaan dalam sebuah layanan konsumen yang dilakukan Ace Hardware nampaknya akan menjadi sebuah terobosan baru bagi Ace Hadware dalam menjawab tantangan kedepan. Pembaruan aplikasi dari yang sudah ada menjadi lebih baru dan lebih kaya fitur tersebut disinyalir sebagai langkah tepat bagi Ace Hardware untuk mengikuti perkembangan jaman. Aplikasi bertajuk MISS ACE (Mobile Interactive Shopping Solution) tersebut memiliki tagline "Personal Acesistant" yang menjadi objek utama dalam penelitian ini. 
Dalam kajian komunikasi, Acesistant merupakan sebuah upaya pengelolaan identitas perusahaan yang bersifat pembaharuan menurut Smith. Sedangkan dalam kajian bahasa, Acesistant dikaji melalui teori blending Lehrer yang memiliki empat turunan dan Algeo memiliki turunan lebih banyak, yaitu enam turunan. Hasil kajian dari kedua pakar blending tersebut menghasilkan temuan bahwa Acesistant masuk kedalam kategori pertama dari sudut pandang Lehrer dimana, penggabungan kata Ace dan Assistant pada kata Acesistant memiliki kesamaan bunyi di suku kata asalnya. Sedangkan pada sudut pandang Algeo, kata Acesistant masuk kedalam kategori kedua, yang cenderung fokus pada pemotongan kata penggabung kedua yaitu ((As)-sistant) yang digabungkan dengan brand Ace sebagai penggabung kata awal Acesistant. Penelitian ini menunjukkan peran tagline sebagai implementasi komunikasi kreatif yang dapat perusahaan atau pebisnis gunakan sebagai upaya dalam mengelola identitas perusahaan. Penciptaan tagline diharapkan dapat dikonsep secara matang, agar tagline tak hanya sekedar kata atau frasa, tapi tagline juga dapat difungsikan sebagai sebuah identitas perusahaan yang utuh dan lebih bermakna.

\section{Daftar Pustaka}

Anita; Ramadhiyanti; Kurniawati. 2014. "PENGETAHUAN MORFOLOGI ( MORPHOLOGICAL AWARENESS ) DALAM PROSES PENGENALAN Inggris Dalam Penggunaan Bahasa Inggrisnya . Pada Kurikulum Pendidikan Bahasa Performa Pelajar, Namun Penguasaan Pengetahuan
Atau Komponen Bahasa Inggris," 103-18.

Arens, W.F. 1996. Contemporary Advertising. 6th ed. Chicago: Irwin.

Giyatmi; Wijayava; Arumi. 2018. "Blending: Sebuah Alternatif A . Pendahuluan Pada Pertengahan Tahun 2016 , Beredar Sebuah Snack Atau Makanan Ringan Yang Cukup Membuat Heboh Masyarakat Indonesia . Snack Tersebut Dikenal Dengan Nama Bikini . Snack Tersebut Dianggap Memiliki Muatan Pornagr." Adabiyyāt: Jurnal Bahasa Dan Sastra II (2): 156-80.

Hosseinzadeh, Naghmeh Mirzaie. 2014. "New Blends in English Language." EA Journals 2.

Knapp, Duanne E. 2001. The Brand Mindset. Yogyakarta: ANDI.

Kotler, Philip, Gary Armstrong. 2001. Prinsip-Prinsip Pemasaran Jilid 2. (Damos Sihombing. Alih Bahasa). Jakarta: Erlangga.

Kushartanti. 2005. Pesona Bahasa: Langkah Awal Memahami Linguistik. Jakarta: PT. Gramedia Pustaka Utama.

Lehrer, Adriene. 2007. Lexical Creativity, Texts Dan Contexts. Amsterdam: John Benjamins Publishing.

Rossiter, J.R., dan Larry, P. 1997. Advertising Communication \& Promotion Management. Boston: Irwin McGraw Hill.

Shimp. Terence. 2014. Komunikasi Pemasaran Terpadu Dan Periklanan Promosi. Jakarta: Salemba Empat.

Smith, P.R. 1998. Marketing Communications, An Integrated Approach. London: Kogan Page.

Stewart, Thomas. W. 2001. Languages Files. USA: The Ohio State University Press. 
Sulaksana, Uyung. 2003. Integrated Marketing Communication. Yogyakarta: Pustaka Pelajar.

Thomas, S. Robertson dan Harold, Kassarjian (ed). Englewood, Cliffs. 1991. Handbook of Consumer Behavior. New York: Prentice-Hall.

Zaim, M. 2015. "Pergeseran Sistem Pembentukan Kata Bahasa Indonesia: Kajian Akronim, Bleding, Dan Kliping." Linguistik Indonesia 33 (2): 173-92.

\section{Internet:}

https://www.kompas.com/homey/read/202 1/03/16/141600976/mudahkan-konsumendalam-berbelanja-ace-hardware-hadirkanlayanan-

ini?utm_source=Facebook\&utm_medium= Refferal\&utm_campaign=Sticky_Dekstop (diakses pada Jumat tanggal 19 Maret 2021 pukul 16:10 WIB) 